\title{
Penggunaan Model Pembelajaran Giving Questions and Getting Answer (GQGA) Sebagai Upaya Meningkatkan Prestasi Belajar IPS
}

\section{Ida Ayu Ketut Resi Asmini*}

\author{
SD Negeri 1 Blahbatuh
}

\author{
A R T I C L E I N F O \\ Article history: \\ Received 12 February \\ 2020 \\ Received in revised form \\ 18 March 2020 \\ Accepted 30 April 2020 \\ Available online 27 May \\ 2020 \\ Kata Kunci: \\ Model Pembelajaran \\ Giving Questions and \\ Getting Answer (GQGA), \\ Prestasi Belajar IPS \\ Keywords: \\ Giving Questions and \\ Getting Answer (GQGA) \\ Learning Model, IPS \\ Learning Achievement
}

\begin{abstract}
A B S T R A K
Penelitian ini dilaksanakan di SD Negeri 1 Blahbatuh di kelas VI yang kemampuan siswanya untuk mata pelajaran IPS cukup rendah. Tujuan penulisan penelitian tindakan kelas ini adalah untuk mengetahui apakah model pembelajaran Giving Questions and Getting Answer (GQGA) dapat meningkatkan prestasi belajar IPS siswa kelas VI SD Negeri 1 Blahbatuh. Metode pengumpulan datanya adalah tes prestasi belajar. Metode analisis datanya adalah deskriptif. Hasil yang diperoleh dari penelitian ini adalah model pembelajaran Giving Questions and Getting Answer (GQGA) dapat meningkatkan prestasi belajar IPS siswa kelas VI SD Negeri 1 Blahbatuh. Ini terbukti dari hasil yang diperoleh pada awalnya 67,74 , pada siklus I menjadi 74,03 dan pada siklus II menjadi 81,45. Jadi, model pembelajaran Giving Questions and Getting Answer (GQGA) dapat meningkatkan prestasi belajar IPS siswa kelas VI SD Negeri 1 Blahbatuh Semester II Tahun Pelajaran 2018/2019.
\end{abstract}

\section{A B S T R A C T}

This research was carried out in SD Negeri 1 Blahbatuh in sixth grade where the ability of students for social studies subjects was quite low. The purpose of writing this class action research is to find out whether the Giving Questions and Getting Answer (GQGA) learning model can improve the social learning achievement of Sixth Grade students of SD Negeri 1 Blahbatuh. The data collection method is a learning achievement test. The data analysis method is descriptive. The results from this study was the Giving Questions and Getting Answer (GQGA) learning model can improve the social learning achievement of Sixth Grade students of SD Negeri 1 Blahbatuh. This is evident from the results obtained initially at 67.74, in the first cycle was 74.03 and in the second cycle was 81.45 . So, the Giving Questions and Getting Answer (GQGA) learning model can improve the social learning achievement of Sixth Grade students of SD Negeri 1 Blahbatuh Semester II in 2018/2019 Academic Year. 


\section{Pendahuluan}

Pendidikan merupakan kegiatan terencana yang berlangsung sepanjang hidup dan menjadi kebutuhan bagi manusia. Pendidikan tidak hanya berlangsung di sekolah, akan tetapi dapat juga berlangsung di dalam keluarga dan masyarakat. Oleh karena itu, pendidikan menjadi tanggung jawab bersama antara keluarga, masyarakat, dan juga pemerintah. Pendidikan memegang peranan penting bagi kehidupan manusia. Tanpa pendidikan manusia akan sulit berkembang atau bahkan tidak berkembang. Dengan demikian, pendidikan harus benarbenar diarahkan agar menghasilkan manusia yang berkembang dan berkualitas serta mampu bersaing, di samping memiliki akhlak dan moral yang baik.

Keberhasilan belajar peserta didik dipengaruhi oleh beberapa faktor, dapat berasal dari diri peserta didik sendiri maupun dari guru sebagai pendidik. Faktor yang berasal dari guru di antaranya kemampuan dalam merancang pembelajaran yang mampu menumbuhkan motivasi belajar peserta didik, menciptakan suasana belajar yang menarik dan menyenangkan. Namun pada kenyataannya, peserta didik masih menganggap matematika sebagai mata pelajaran yang menakutkan sehingga susah untuk dipahami. Hal ini terjadi karena pendidik belum mampu mengemas pembelajaran matematika menjadi lebih menyenangkan yang mampu menarik perhatian peserta didik. Sehingga membuat prestasi belajar peserta didik tidak sesuai dengan yang diharapkan.

Proses pembelajaran saat ini masih cenderung menempatkan guru sebagai pusat pembelajaran atau satu-satunya sumber belajar. Guru hanya sekedar memberikan pengetahuan kepada siswa. Siswa tidak diberikan kesempatan untuk membangun sendiri pengetahuan yang dimilikinya. Tentunya keadaan seperti itu berpengaruh pada hasil belajar siswa. Untuk itu perlu adanya perubahan dalam proses pembelajaran dimana dalam proses pembelajaran lebih diarahkan pada keaktifan siswa. Guru dapat memberikan kesempatan kepada siswa untuk membangun sendiri pengetahuan mereka serta guru bukan satu-satunya sebagai sumber belajar. Oleh karena itu, guru diharapkan mampu memilih model pembelajaran yang sesuai dengan materi pembelajaran agar diperoleh hasil belajar siswa yang baik. (Ayuwanti, 2016).

Pendidikan Salah satu tujuan didirikannya negara Indonesia ialah untuk mencerdaskan kehidupan bangsa. Tujuan tersebut tertuang di dalam alinea IV pembukaan Undang-undang Dasar Republik Indonesia Tahun 1945 (UUD RI 1945). Mencerdaskan kehidupan bangsa dapat diwujudkan melalui pendidikan. Sistem pendidikan yang baik akan melahirkan generasi bangsa yang cerdas dan baik pula. Generasi bangsa yang cerdas ialah modal awal bagi suatu bangsa dalam melakukan pembangunan ke arah yang lebih baik dalam usaha mencapai pembangunan nasional. Pembangunan yang dilakukan oleh suatu bangsa menandakan bahwa bangsa tersebut merupakan bangsa yang bermartabat karena selalu melakukan peningkatan kualitas dan beradaptasi dengan peradaban zaman.

Dari pernyataan tersebut tersirat pesan bahwa pendidikan perlu mendapatkan perhatian yang serius. Melihat begitu pentingnya peran pendidikan, maka pemerintah merumuskan fungsi dan tujuan pendidikan nasional dalam Undang-undang Sistem Pendidikan Nasional. Dalam Undang-undang Sistem Pendidikan Nasional No. 20 tahun 2003 pasal 1 ayat 1 disebutkan bahwa pendidikan adalah usaha sadar dan terencana untuk mewujudkan suasana belajar dan proses pembelajaran agar siswa secara aktif mengembangkan potensi dirinya untuk memiliki kekuatan spiritual keagamaan, pengendalian diri, kepribadian, kecerdasan, akhlak mulia, serta keterampilan yang diperlukan dirinya, masyarakat, bangsa, dan negara.

Upaya untuk mencapai tujuan pendidikan nasional bukanlah hal yang sepele. Pelaksana pendidikan baik yang membuat kebijakan maupun yang terjun langsung di lapangan harus bekerjasama dengan baik. Pelaksana pendidikan yang terjun langsung di lapangan atau yang lazim disebut guru merupakan subjek yang sangat berpengaruh terhadap hasil pendidikan. Semakin baik seorang guru dalam menyampaikan materi maka semakin baik pula hasil belajar siswa dan akan semakin baik pula hasil pendidikan.

Salah satu upaya untuk mendapatkan hasil belajar yang baik ialah guru harus menjalankan perannya dengan optimal. Menurut Anni (2007: 102), peran guru dalam pendekatan humanistik adalah sebagai fasilitator belajar. Peran guru sebagai fasilitator berarti guru membantu siswa untuk belajar. Menurut Gagne dalam Sagala (2010: 13), belajar adalah suatu proses dimana suatu organism berubah perilakunya. Perubahan perilaku tersebut meliputi tiga ranah belajar yakni ranah kognitif (pengetahuan), afektif (nilai dan sikap), dan psikomotorik (keterampilan). Dalam kegiatan pembelajaran, guru sebagai fasilitator harus mampu mengondisikan siswa dan lingkungan supaya siswa mampu belajar dan mendapatkan perubahan tingkah laku dari ketiga ranah tersebut sebab ketiga ranah tersebut merupakan pembentuk kepribadian individu.

Model pembelajaran yang dapat digunakan guru dalam upaya meningkatkan prestasi belajar IPS siswa adalah dengan menerapkan Model pembelajaran Giving Questions and Getting Answer (GQGA). Model pembelajaran GQGA memiliki langkah-langkah mengutamakan siswa dapat menemukan ilmu yang 
terdapat dalam materi pembelajaran dengan cara mencari sendiri. Guru dalam hal ini hanya sebagai motivator dan fasilitator. Model ini menuntut kegiatan intelektual yang tinggi, memproses apa yang mereka telah dapatkan dalam pikirannya untuk menjadi sesuatu yang bermakna. Mereka diupayakan untuk lebih produktif, mampu membuat analisa, membiasakan mereka berpikir kritis, dapat mengingat lebih lama, materi yang telah mereka pelajari. Model ini juga bisa diupayakan untuk pengembangan kemampuan akademik, menghindarkan siswa belajar dengan hapalan, dapat memberikan tambahan kemampuan untuk dapat mengasimilasikan dan mengakomodasikan informasi, serta menuntut latihanlatihan khusus untuk mempertinggi daya ingat dengan berlatih untuk dapat menemukan sendiri sesuatu yang penting dalam materi yang diberikan.

Berdasarkan pemaparan di atas maka dalam penelitian ini akan mengambil judul tentang Penggunaan Model Pembelajaran Giving Questions and Getting Answer (GQGA) Sebagai Upaya Meningkatkan Prestasi Belajar IPS Melalui Siswa Kelas VI SD Negeri 1 Blahbatuh Semester II Tahun Pelajaran 2018/2019. Adapun hipotesis yang dapat diajukan pada penelitian ini adalah "Jika langkahlangkah Model pembelajaran Giving Questions and Getting Answer (GQGA) diterapkan secara maksimal maka Prestasi Belajar Siswa Kelas VI SD Negeri 1 Blahbatuh pada Semester II Tahun Pelajaran 2018/2019 dapat ditingkatkan".

\section{Metode}

Penelitian yang dilakukan termasuk penelitian tindakan. Oleh karenanya, rancangan yang khusus untuk sebuah penelitian tindakan sangat diperlukan. Berdasarkan sudut pandang pencapaian tujuan penelitian, rancangan penelitian berfungsi sebagai pedoman kerja (peta pedoman pengarahan bagipelaksanaan penelitian). Fungsi lain,rancangan penelitian adalah sebagai rambu-rambu penentuan atau tolok ukur keberhasilan penelitian yang akan dilaksanakan. Memberikan petunjuk mengenai ukuranukuran sampai dimana penelitian yang dilakukan itu dikatakan mencapai hasil yang diinginkan.

Untuk penelitian ini penulis memilih rancangan penelitian tindakan yang disampaikan oleh Suharsimi Arikunto, Suhardjono, Supardi seperti terlihat pada gambar berikut.

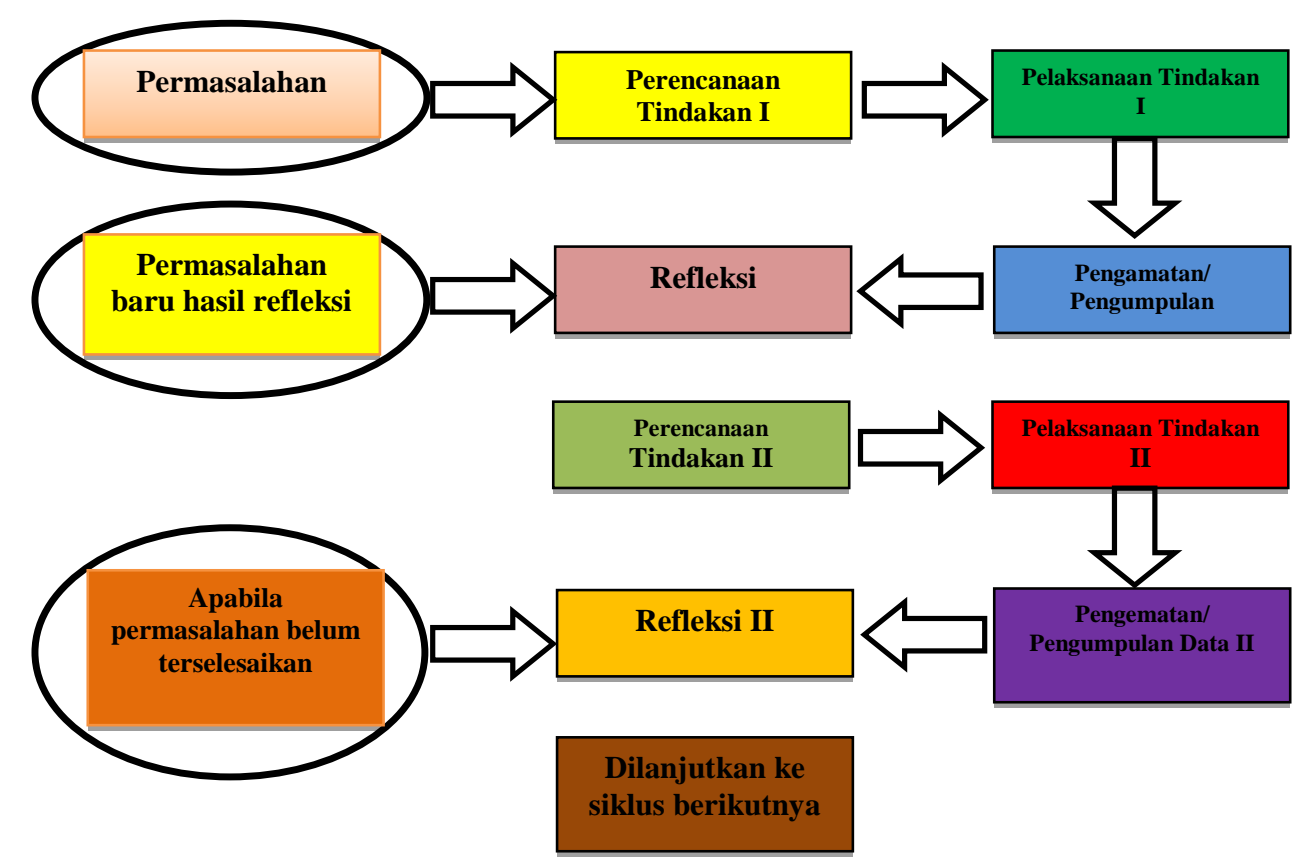

Gambar .1 Alur Penelitian Tindakan Kelas (dalam Suharsimi Arikunto, Suhardjono, Supardi, 2007: 74

Pada tahap perencanaan peneliti membuat RPP, berkonsultasi dengan teman sejawat membuat instrumen.Pada tahap menyusun rancangan diupayakan ada kesepakatan antara guru dan sejawat. Rancangan dilakukan bersama antara peneliti yang akan melakukan tindakan dengan guru lain yang akan mengamati proses jalannya tindakan. Hal tersebut untuk mengurangi unsur subjektivitas pengamat serta mutu kecermatan pengamatan yang dilakukan.

Tahap pelaksanaan tindakan dilakukan dengan pembelajaran di kelas. Pada tahap ini guru peneliti giat melakukan tindakan menggunakan Model pembelajaran Giving Questions and Getting Answer (GQGA). 
Rancangan tindakan tersebut sebelumnya telah dilatih untuk dapat diterapkan di dalam kelas sesuai dengan skenarionya. Skenario dari tindakan diupayakan dilaksanakan dengan baik dan wajar.

Tahap pengamatan atau observasi sebenarnya berjalan bersamaan dengan saat pelaksanaan. Pengamatan dilakukan pada waktu tindakan sedang berjalan, jadi, keduanya berlangsung dalam waktu yang sama.Pada tahap ini,guru yang bertindak sebagai peneliti melakukan pengamatan dan mencatat semua hal yang diperlukan dan terjadi selama pelaksanaan tindakan berlangsung. Pengumpulan data ini dilakukan dengan menggunakan tes prestasi belajar yang telah tersusun, termasuk juga pengamatan secara cermat pelaksanaan skenario tindakan dari waktu ke waktu serta dampaknya terhadap proses dan hasil belajar anak.

Tahapan refleksi untuk mengkaji secara menyeluruh tindakan yang telah dilakukan, berdasarkan data yang telah terkumpul, kemudian dilakukan evaluasi guna menyempurnakan tindakan berikutnya. Refleksi dalam PTK mencakup analisis, sintesis, dan penilaian terhadap hasil pengamatan atas tindakan yang dilakukan. Jika terdapat masalah dari proses refleksi maka dilakukan proses pengkajian ulang melalui siklus berikutnya Pengumpulan data dalam penelitian ini menggunakan tes prestasi belajar. Tes prestasi belajar berupa tes soal isian maupaun esay. Untuk menganalisis data hasil penelitian ini digunakan metode deskriptif. Untuk data kuantitatif dianalisis dengan mencari mean, median, modus, membuat interval kelas dan melakukan penyajian dalam bentuk tabel dan grafik.

Indikator keberhasilan penelitian yang diusulkan dalam penelitian ini pada siklus I dan II mencapai nilai rata-rata 75,00 dengan ketuntasan belajar 85\%. dengan KKM yang ditetapkan untuk mata pelarajan IPS pada SD Negeri 1 Blahbatuh adalah 75.

\section{Hasil dan Pembahasan}

Penelitian Model pembelajaran Giving Questions and Getting Answer (GQGA) merupakan implementasi dari strategi pembelajaran kontrukstivistik yang menempatkan siswa sebagai subyek dalam pembelajaran. Artinya, siswa mampu merekonstruksi pengetahuannya sendri sedangkan guru hanya sebagai fasilitator saja. Model Giving Questions and Getting Answer ditemukan oleh Spancer Kagan, orang berkebangsaan Swiss pada tahun 1963. Model ini dikembangkan untuk melatih siswa memiliki kemampuan dan ketrampi lan bertanya dan menjawab pertanyaan, karena pada dasarnya model tersebut merupakan modifikasi dari metode tanya jawab dan metode seramah yang merupakan kolaborasi dengan menggunakan potongan-potongan kertas sebagai medianya.

Kegiatan bertanya dan menjawab merupakan hal yang sangat esensial dalam pola interaksi antara guru dan siswa. Kegiatan bertanya dan menjawab yang dilakukan oleh guru dan siswa dalam proses belajar mengajar mampu menumbuhkan pengetahuan baru pada diri siswa. Model Giving Questions and Getting Answer (GQGA) dilakukan bersamaan antara metode tanya jawab dengan metode ceramah, agar siswa tidak dalam keadaan blank mind. Metode ceramah sebagai dasar agar siswa mendapatkan pengetahuan dasar (prior knowledge).

Kelebihan penerapan metode Active Learning model Giving Questions and Getting Answers (GQGA) adalah suasana lebih menjadi aktif, anak mendapat kesempatan baik secara individu maupun kelompok untuk menanyakan hal-hal yang belum di mengerti, guru dapat mengetahui penguasaan anak terhadap materi yang disampaikan, mendorong anak untuk berani mengajukan pendapatnya.

Berdasarkan penelitian yang telah dilakukan, didapatkan hasil sebagai berikut. Data awal yang diperoleh dengan rata-rata 68,10 menunjukkan bahwa kemampuan anak/siswa dalam mata pelajaran IPS masih sangat rendah mengingat kriteria ketuntasan belajar siswa untuk mata pelajaran ini di SD Negeri 1 Blahbatuh adalah 75,00. Dengan nilai yang sangat rendah seperti itu maka peneliti mengupayakan untuk dapat meningkatkan prestasi belajar anak/siswa menggunakan model pembelajaran Giving Questions and Getting Answer (GQGA). Akhirnya dengan penerapan model pembelajaran Giving Questions and Getting Answer (GQGA) yang benar sesuai teori yang ada, peningkatan rata-rata prestasi belajar anak/siswa pada siklus I dapat diupayakan dan mencapai rata-rata 74,03. Namun rata-rata tersebut belum maksimal karena hanya 21 siswa memperoleh nilai di atas KKM sedangkan yang lainnya belum mencapai KKM. Sedangkan prosentase ketuntasan belajar mereka baru mencapai $67,74 \%$. Hal tersebut terjadi akibat penggunaan model pembelajaran Giving Questions and Getting Answer (GQGA) belum maksimal dapat dilakukan disebabkan penerapan model/metode tersebut baru dicobakan sehingga guru masih belum mampu melaksanakannya sesuai alur teori yang benar.

Pada siklus ke II perbaikan prestasi belajar siswa diupayakan lebih maksimal dengan peneliti membuat perencanaan yang lebih baik, menggunakan alur dan teori dari model pembelajaran Giving Questions and Getting Answer (GQGA) dengan benar dan lebih maksimal. Peneliti giat memotivasi siswa agar giat belajar, memberi arahan-arahan, menuntun mereka untuk mampu menguasai materi pelajaran 
pada mata pelajaran IPS lebih optimal. Akhirnya dengan semua upaya tersebut peneliti mampu meningkatkan prestasi belajar siswa pada siklus II menjadi rata-rata 81,20. Upaya-upaya yang maksimal tersebut menuntun kepada penelitian bahwa metode pembelajaran Giving Questions and Getting Answer (GQGA) mampu meningkatkan prestasi belajar IPS siswa kelas VI SD Negeri 1 Blahbatuh Semester II Tahun Pelajaran 2018/2019.

Semua hasil yang diperoleh dari awal, siklus I dan siklus II dipaparkan dalam bentuk tabel dan grafik seperti berikut:

Tabel 1 : Tabel Data Prestasi Belajar Siswa kelas VI SD Negeri 1 Blahbatuh

\begin{tabular}{lllll}
\hline DATA & AWAL & SIKLUS I & SIKLUS II & VARIABEL \\
\hline Skor Nilai & 2100 & 2295 & 2525 & Prestasi Belajar IPS \\
Rata Rata Kelas & 67,74 & 74,03 & 81,45 & Dengan \\
Persentase Ketuntasan & $41,93 \%$ & $67,74 \%$ & $93,54 \%$ & KKM = 75 \\
\hline
\end{tabular}

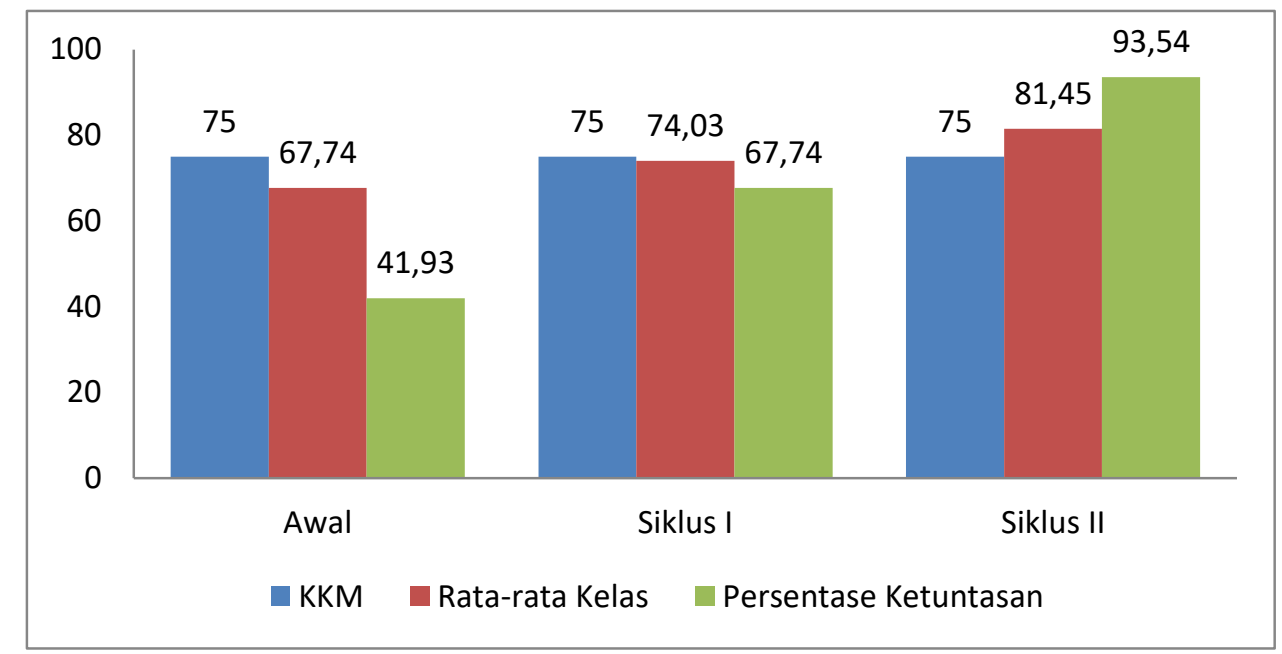

Gambar 2. Grafik Histogram Prestasi Belajar IPS siswa kelas VI semester II tahun pelajaran 2018/2019 SD Negeri 1 Blahbatuh

Hasil penelitian ini sejalan dengan hasil penelitian yang dilakukan oleh Sukriyah Wijayanti pada tahun 2014 dengan judul Penerapan Model Pembelajaran Giving Question And Getting Answer (GQGA) Untuk Meningkatkan Keaktifan Belajar Siswa. Hasil penelitian menunjukkan bahwa persentase keaktifan belajar siswa mengalami peningkatan yaitu dari 67,19\% pada siklus I dengan kategori cukup menjadi 78,91\% pada siklus II dengan kategori baik. Sedangkan rata-rata hasil belajar siswa siklus I mencapai 65,63 dengan ketuntasan klasikal 53,13\% dan rata-rata hasil belajar siswa siklus II mengalami peningkatan menjadi 75,34 dengan ketuntasan klasikal 78,13\%. Dari hasil penelitian dapat disimpulkan bahwa penerapan model pembelajaran GQGA dapat meningkatkan keaktifan belajar siswa kelas VIII C SMP Negeri 15 Purworejo Tahun Pelajaran 2013/2014.

Penelitian yang dilakukan oleh Yeni Dwi Kurino pada tahun 2018 dengan judul Model Giving Question and Getting Answer Untuk Meningkatkan Hasil Belajar Siswa Sekolah Dasar. Berdasarkan hasil penelitian dengan menggunakan model pembelajaran Model Giving Question and Getting Answer, maka Hasil Belajar meningkat. Hal ini terlihat pada tes yang diberikan peneliti kepada seliuruh siswa dikelas $\mathrm{V}$ Sekolah Dasar yaitu terdapat peningkatan dari rata-rata nilai Hasil belajar Pada data awal ketuntasan siswa berada pada 11,76\%. Selanjutnya, pada siklus I ketuntasan meningkat sebanyak 55,88\% dan ketuntasan siswa pada siklus I menjadi 67,64\%. Pada siklus II, ketuntasan siswa kembali meningkat sebanyak 8,83\% dan ketuntasan siswa menjadi 76,47\%. Interaksi siswa dengan siswa maupun siswa dengan guru lebih kondusif, Hasil Belajar siswa tiap tindakan selama penelitian berlangsung mengalami peningkatan. 


\section{Simpulan Dan Saran}

Bertumpu pada rendahnya prestasi belajar siswa yang disampaikan pada latar belakang masalah, penggunaan model pembelajaran Giving Questions and Getting Answer (GQGA) diupayakan untuk dapat menyelesaikan tujuan penelitian ini yaitu untuk mengetahui peningkatan prestasi belajar. Seberapa besar peningkatan yang dicapai sudah dipaparkan dengan jelas pada akhir analisis. Dari hasil penelitian yang disampaikan di Bab IV dan melihat semua data yang telah disampaikan, tujuan penelitian yang disampaikan di atas dapat dicapai dengan bukti sebagai berikut:

Kenaikan prestasi belajar siswa dapat dilihat dari bukti-bukti berikut:

a. Dari data awal ada 18 siswa mendapat nilai dibawah KKM dan pada siklus I menurun menjadi 10 siswa dan siklus II hanya 2 siswa mendapat nilai di bawah KKM.

b. Dari rata-rata awal 67,74 naik menjadi 74,03 pada siklus I dan pada siklus II naik menjadi 81,45.

c. Dari data awal siswa yang tuntas hanya 13 orang sedangkan pada siklus I menjadi lebih banyak yaitu 21 siswa dan pada siklus II menjadi cukup banyak yaitu 29 siswa.

Dari semua data pendukung pembuktian pencapaian tujuan pembelajaran dapat disampaikan bahwa model pembelajaran Giving Questions and Getting Answer (GQGA) dapat memberi jawaban yang diharapkan sesuai tujuan penelitian ini. Semua ini dapat dicapai adalah akibat kesiapan dan kerja keras peneliti dari sejak pembuatan proposal, review hal-hal yang belum bagus bersama teman-teman guru, penyusunan kisi-kisi dan instrumen penelitian, penggunaan sarana trianggulasi data sampai pada pelaksanaan penelitian yang maksimal.

Berdasarkan temuan yang sudah disimpulan dari hasil penelitian, dalam upaya mencapai tujuan pembelajaran dalam bidang studi IPS, dapat disampaikan saran-saran sebagai berikut:

1. Dalam melaksanakan proses pembelajaran pada mata pelajaran IPS, penggunaan model pembelajaran Giving Questions and Getting Answer (GQGA) semestinya menjadi pilihan dari beberapa metode yang ada mengingat metode ini telah terbukti dapat meningkatkan kerjasama, berkreasi, bertindak aktif, bertukar informasi, mengeluarkan pendapat, bertanya, berdiskusi, berargumentasi dan lain-lain.

2. Walaupun penelitian ini sudah dapat membuktikan efek utama dari model pembelajaran Giving Questions and Getting Answer (GQGA) dalam meningkatkan prestasi belajar, sudah pasti dalam penelitian ini masih ada hal-hal yang belum sempurna dilakukan, oleh karenanya kepada peneliti lain yang berminat meneliti topik yang sama untuk meneliti bagian-bagian yang tidak sempat diteliti.

3. Selanjutnya untuk adanya penguatan-penguatan, diharapkan bagi peneliti lain untuk melakukan penelitian lanjutan guna verifikasi data hasil penelitian.

\section{Daftar Rujukan}

Anni, Catharina Tri. 2007. Psikologi Belajar. Semarang: UPT Unnes press.

Arikunto, Suharsimi., Suhardjono, Supardi. 2007. Penelitian Tindakan Kelas. Jakarta: Bumi Angkasa. Departemen Pendidikan Nasional.

Ayuwanti, Irma . Meningkatkan Aktivitas Dan Hasil Belajar Matematika Menggunakan Model Pembelajaran Kooperatif Tipe Group Investigation Di Smk Tuma'ninah Yasin Metro . Jurnal SAP Vol. 1 No. 2 Desember 2016

Azwar, Saifuddin. 2003. Penyusunan Skala Psikologi. Yogyakarta: Pustaka Pelajar.

Badan Standar Nasional Pendidikan. 2007. Peraturan Menteri Pendidikan Nasional Republik Indonesia Nomor 41 Tahun 2007. Jakarta: BSNP.

Dahar, Ratna Wilis. 1989. Teori-Teori Belajar. Jakarta: Penerbit Erlangga.

Dimyati dan Mudjiono. 2001. Belajar dan Pembelajaran. Jakarta: Dirjen Dikti.

Djamarah, Syaful Bahri. 2002. Prestasi Belajar dan Kompetensi Guru. Surabaya: Usaha Nasional.

Fernandes, H.J.X. 1984. Testing and Measurement. Jakarta. National Education Planning, Evaluation and Curriculum Development. 
Fraenkel, Jack R. and Norman E. Wallen. 1993. How to Design and Evaluate Research in Education. Second Edition. New York: McGraw-Hill, Inc.

Gagne, Robert M. 1977. The Conditions of Learning. Third Edition. New York: Holt, Reinhart and Winston.

Good, Thomas L. \& Jere E. Brophy. 1990. Educational Psychology, A Realistic Approach. New York: Longman.

Gregory, Robert J. 2000. Psychological Testing: History, Principles, and Applications. Boston: Allyn and Bacon.

Kurino, Yeni Dwi. 2018. Model Giving Question and Getting AnswerUntuk Meningkatkan Hasil Belajar Siswa Sekolah Dasar. Jurnal Didactical Mathematics Vol. 1 No. 1, 2018 hal. 34-39.

Sagala, Syaiful. 2010. Konsep dan Makna Pembelajaran. Bandung: Alfabeta.

Undang-undang Sistem Pendidikan Nasional No. 20 tahun 2003

Wijayanti, Sukriyah. 2014. Penerapan Model Pembelajaran Giving Question And Getting Answer (GQGA) Untuk Meningkatkan Keaktifan Belajar Siswa. Jurnal Ekutvalen Pendidikan Matematika Volume 12 Nomor 1. 